\title{
Public Participation: A New Attempt on Modern Community Governance
}

\author{
Libin Jia \\ Chongqing City Management College, Chongqing City, China, 401331
}

Keywords: Public participation, Community governance, Modern community, Path of realization.

\begin{abstract}
Promoting the modernization of community governance is not only the overall goal of comprehensively deepening the reform of community governance system, but also the basic way to realize the modernization of community governance. As a new form of democracy, public participation has gained initial application in community governance in recent years. Based on the learning and practical experience, this paper firstly analyzed the connotation of public participation in community governance, and then discussed the problems of public participation in community governance, and finally put forward the ways of public participation in community governance. Public participation can greatly improve people's awareness of modern citizens and the enthusiasm of residents' autonomy, and has certain research value and practical significance to promote the reform of the community comprehensive governance model.
\end{abstract}

\section{Introduction}

The public participation theory can be traced back to twentieth Century 60-70 years. The United States first introduced the concept of public participation in the National Environmental Policy Act, which was subsequently learned by many countries. In 1978, the United Nations Environment Programme (UNEP) further defined the meaning and value of public participation in its basic procedures for environmental impact assessment. From the perspective of community governance, public participation is an active participation of citizens in community governance within the scope of their rights, and is conducive to the formation of effective and positive interaction with government departments. As a result, it helps to build community_and promote social harmonious development. Public participation in community governance is a sign of the democratic process. It also shows the democratic advancement degree of a nation or a country with the degree of the participation.

\section{The Connotation of Public Participation in Community Governance}

In the community, public organizations are represented by neighborhood committees. Although the neighborhood committee has been given the name of the autonomous organization in the law, the neighborhood committee plays a more important role in the community and is a standard government organization in the eyes of the residents. Residents can reflect and make comments on the disputes and grievances caused by public problems in the community so as to effectively participate in community governance. In the process of public participation in community governance, public institutions are the main part of public participation, and they are the dominant parties. The public is the participant, and is generally the passive side. But in fact, the public participation in our community has its own characteristics, and the public is not entirely passive. When the relevant government departments do not take the initiative to open the channels of public participation, civil and social organizations will exert influence on the spontaneous behavior of community governance through the organization of the media or the appropriate means, forcing public agencies and the public to interact. Therefore, many of our public participation are pressured-styled forms from bottom to the top and from outside to inside. This characteristic reflects the needs and actions of the public to express their opinions and participate in public 
governance. Thus, the government is aware of the need for public participation and opens up channels for public participation. In this process, the government is in a forced state rather than the dominant party that actively guides public participation. To solve the above mentioned problems in dogs and safeguard their own interests, community residents take the initiative to seek guidance from neighborhood, so as to promote problem solving through the collective wisdom of discussion and consultation led by neighborhood. It is worth noting that only unilateral action without interaction process can not be called public participation.

\section{Problems of Public Participation in Community Governance}

The openness and transparency of public information in the community is not high. Public participation is based on effective information. Without full transparent information, public participation can only be blind, and opinions are meaningless. It can be said that the right to know is the premise of the right to participate. Taking the community Consultative Council for example, most of the community councils were held by the community for the task of completing the street assignment. Most of the participants are members of the neighborhood committees and resident units. Because of the lacking prior knowledge of the theme of the meeting and low relevance with the daily life of the residents, the voice and participation of the residents were relatively low. Therefore, the government's practice of keeping the public information in the community not only reduces the public's judgment, but also seriously affects the public's enthusiasm for community governance.

The development of community civil organizations is bad. At present, the development of civil organizations in China is restricted in many ways, including high entry threshold, complicated application procedures, harsh examination and approval conditions and many civil organizations being unable to obtain the legitimacy of existence for they can not find suitable units. Some have to change their appearance and seek legal registration in the form of business registration. They carry out non-profit philanthropy and public welfare activities in the name of profit-making enterprises. Industry and commerce registration must be paid according to the standard of enterprise, which makes the community non-governmental organizations that rely on social donations to carry out activities overwhelmed. In addition, the government departments often ignore the development of civil organizations in their attitude, and the management of them still rests on the passive management level of registration and filing with insufficient management power. Therefore, community organizations without legal protection and the source of funds will be perished by themselves. Moreover, the low level of professionalism of civil organizations and the lack of professionalism and necessary welfare benefits and incentive mechanisms of these organizations have greatly suppressed the channels and opportunities for public participation in community governance.

The supporting mechanism of public participation is unsound. Many communities now have a service hotline, and residents can reflect the problems of government departments in community management and services through the community service hotline. These problems are then conveyed to the relevant functional departments by the neighborhood committee through the e-government platform. However, there is only the unilateral views of the residents to express the process, and the relevant government departments on establishing a corresponding response, handling the formula and supervision mechanism are insufficient. In the course of time, public participation is bound to be affected. obviously, the small degree of public participation is a systemic problem.

\section{Paths of Realization for Public Participation in Community Governance}

Change the management function and respect the status of community residents. So far, the public participation in China is still in its infancy, and has not been paid enough attention to. In the management mode, the government still stays in the traditional management concept. The modernization of community governance requires the government to change its functions: First of 
all, it should transform from an omnipotent government to a particular type of government. Nowadays, social needs are diverse, and the government is not omnipotent in terms of national governance. When giving full play to the leading role, the government should mobilize and organize other social forces to participate in the social governance in an orderly manner, so that to clearly know the respective responsibilities of the government, the market and the society. Secondly, it should transform from a regulatory government into a service-oriented government. With the continuous development and reform of the society, the citizens will make more demands for government administration. The government are required to provide high-quality services, establish a service-oriented concept, effectively fulfill the functions of social management and public services, implement management in service and embody services in management. Experience tells us that any major reform must be carried out on the people's side. To correctly handle the major issues of reform, we should proceed from the interests of the people, plan the strategy of reform and formulate measures for reform. The social progress that China has made the world focus on is the result of a strong reliance on the strength of the people throughout the country. Therefore, we should truly be people-oriented and respect for the status of the residents, so that the majority of the residents in real and effective participation is the proper meaning of the modernization of community governance.

Cultivate social organizations and improve the mechanism of expression of interests. China is a big country with population, and effective public participation in limited time requires active cooperation from social organizations, so that to realize the industrialization and organization of the group. These groups are not limited to groups of organizations close to the government, but are more of a non political group and community formed by the public. These groups represent the interests and aspirations of the public and represent the public interest. It should be pointed out that the public organizations do not oppose the government, but choose an effective way to improve the rationality of government decision-making, so that to facilitate the government on governing society according to law and improve governance capability. To strengthen the cultivation and support of social groups can coordinate public preferences and reduce the cost of negotiating with the public. We should start with the following aspects: First, it is policy support. They should change the high threshold of the original social group and simplify the registration process of the organization. Second, it is financial support. The government has increased its support for social organizations by purchasing services or providing offices and other indirect means. Third, it is to strengthen community autonomy. With the reform of our social system, the gradual deepening of community construction and the change of social structure, the community becomes more and more independent. Community autonomy has become a new and feasible governance model.

Interaction of government, community and public improves community governance. Generally speaking, residents are not aware of or involved in the decision-making process in some communities. The credibility of the government is a kind of public evaluation and recognition of the government's governance of society. The government must aim at maximizing the interests of its citizens and consciously provide high quality services to the people. Moreover, the public generally depends on the state of the government and lacks the sense of social responsibility. Once a crisis occurs, the government is the first to think. To strengthen the credibility of the government is to coordinate the various strata and interest groups, and improve the transparency and self-management ability of public participation. In addition, we should strengthen the government's social management function and improve the government and community governance capability.

Broaden communication channels and ensure transparency and effectiveness of participation. First, social public hearings should be carried out. When the government makes important decisions, it should not only fully understand the broad interests of the public, but also select the people who have a certain representation so that to balance the interests of all parties through consultation. This hearing system not only enhances the openness and transparency of the information, but also coordinates the interests of all parties and wins public trust. Second, the community meeting should be carried out. The community is a gathering place for the public, which is open to residents and more accessible to the public. This is more suitable for government policy 
propaganda and publicity division.

\section{Summary}

It is an effective way to improve community comprehensive governance through public participation. Public participation can not only coordinate the interaction between community residents, communities and related organizations through various activities, but also reflect the feelings and wishes of the residents in the community, so that to manage, appraise, make decisions and supervise the major affairs of the community. In this way, public participation fully reflects the public awareness, social awareness and public welfare of the community residents. As a result, it is conducive for community residents to achieve common interests, rights, purpose and value with the purpose of forming a good spirit of volunteerism, humanistic spirit, the rule of law spirit and autonomy spirit.

\section{References}

[1] Zhang Chengan, Zou Yanan. Reflection and Path: Public Participation in the Construction of Community[J]. Journal of Yangzhou University (Humanities and Social Science Edition), 2017, (01): $72-76$.

[2] Ma Lihua. New Mechanism for Community Governance[J]. Civil Affairs of China, 2015, (03): 23-24.

[3] Wang Zhidan. Analysis of the Action Framework of Public Participation in Community Governance[J]. Journal of Huaihai Institute of Techology (Humanities and Social Science Edition), 2014, (08): 11-13.

[4] Jiang Yanan. Effective Way of Public Participation and Improving the Level of Community Comprehensive Management[J]. Social Science Journal of Jiamusi University, 2013, (05): 64-66.

[5] Wang Huan. Study on Public Participation in Urban Community Governance[J]. North Economics and Trade, 2013, (08): 38-39.

[6] Zheng Lan. Public Participation in the Governance of Urban Communities[J]. People's Forum, 2011, (29): 246-247.

[7] Liu Zhongqi. On the Path of Public Participation in the International Community[J]. Gansu theory Journal, 2011, (01): 48-51. 